\title{
PENGARUH MODEL PEMBELAJARAN PREDICT, OBSERVE AND EXPLAIN (POE) TERHADAP KEMAMPUAN BERPIKIR KRITIS SISWA
}

\author{
Baiq Munawaratul Islamiyah*, Syarifa Wahidah Al Idrus, Yunita Arian Sani Anwar \\ 1,2,3 Program Studi Pendidikan Kimia FKIP Universitas Mataram \\ *Coressponding Author, Email: baiqmunaislamiyah97@gmail.com
}

Received: 23 Juli 2019

Accepted: 30 November 2019

Publish: 30 November 2019

doi: 10.29303/cep.v2i2.1294

\begin{abstract}
ABSTRAK
Penelitian ini bertujuan untuk mengetahui pengaruh model pembelajaran Predict, Observe and Explain (POE) terhadap kemampuan berpikir kritis siswa materi larutan elektrolit dan non elektrolit kelas $\mathrm{X}$ MIA MAN 2 Mataram. Jenis penelitian ini merupakan quasy eksperimen dalam bentuk rancangan post-test only control group design. Populasi dalam penelitian ini meliputi seluruh siswa kelas X MIA MAN 2 Mataram. Teknik pengambilan sampel yang digunakan yaitu purposive sampling. Sampel pada penelitian ini yaitu kelas X MIA 2 sebagai kelas kontrol dan X MIA 3 sebagai kelas eksperimen. Pada kelas eksperimen diberi perlakuan dengan menggunakan model pembelajaran Predict, Observe and Explain (POE) sedangkan kelas kontrol diberi perlakukan dengan menggunakan model pembelajaran konvensional. Indikator kemampuan berpikir kritis yang diukur dalam penelitian ini yaitu kemampuan memberikan penjelasan sederhana dan kemampuan menyimpulkan. Uji hipotesis pada penelitian ini menggunakan Anova. Hasil uji hipotesis pada taraf signifikan 5\% menunjukkan Fhitung $(0,00605)<$ Ftabel $(3,98)$ yang berarti H0 diterima dan Ha ditolak. Berdasarkan nilai signifikansi diperoleh $0,05<$ sig. 0,938 yang lebih menguatkan bahwa $\mathrm{H} 0$ diterima yang berarti model pembelajaran Predict, Observe and Explain (POE) tidak memberikan pengaruh yang signifikan terhadap kemampuan berpikir kritis siswa pada materi larutan elektrolit dan non elektrolit.
\end{abstract}

Kata kunci : Model Pembelajaran Predict, Observe and Explain (POE), Kemampuan Berpikir Kritis, Larutan Elektrolit dan Nonelektrolit

\section{THE EFFECT OF PREDICT, OBSERVE AND EXPLAIN (POE) LEARNING MODELS ON CRITICAL THINKING SKILL SUBJECT OF ELECTROLITE SOLUTION AND NONELEKTROLIT STUDENT AT CLASS X MIA MAN 2 MATARAM}

\begin{abstract}
This research aims to investigate the effect of Predict, Observe And Explain (POE) learning models on students' critical thinking skill about Electrolite solution and Nonelectrolit in grade X MIA class of MAN 2 Mataram. This research is considered as a quasy experiment in the form of form of post-test only control group design. The population of this research was all students of grade X MIA class in MAN 2 Mataram. The sampling technique used was purposive sampling technique. The sample of this study was X MIA 2 as the control class and X MIA 3 as the experiment class. The experiment class was given treatment using Predict, Observe and Explain (POE) learning model meanwhile, the control class was given conventional learning model. Indicators of critical thinking skills measured in this study are the ability to provide simple explanations and concluding abilities. The hypothesis testing used in this study was Anova. The Hypothesis test result is at 5\% significance level indicate $\mathrm{F}$ count $(0,00605)<\mathrm{F}$ table $(3,98)$ which means $\mathrm{H} 0$ is accepted and Ha is rejected. Based on the significance
\end{abstract}




\section{Chemistry Education Practice,2 (2), 2019 - 15}

Lalu Ardian Gunawan, Sukib, Aliefman Hakim

value obtained $0,05<$ sig. 0,938 which further confirms that $\mathrm{H} 0$ is accepted which means that the Predict, Observe and Explain (POE) learning models does not have a significant effect on students critical thinking skill in subject of Electrolite solution and Nonelectrolit.

Keywords : Predict, Observe And Explain (POE) learning models, critical thinking skill, Electrolite solution and Nonelectrolit

\section{PENDAHULUAN}

Berdasarkan Kemdikbud (2014) salah satu karakteristik yang dibutuhkan dalam pembelajaran kurikulum 2013 yakni HOTS (High Order Thinking Skill) yang meliputi analisis, sintesis, evaluasi bahkan sampai kreatif. Salah satu keahlian yang dibutuhkan pada abad ke-21 yakni kemampuan berpikir kritis dan pemecahan masalah. Kemampuan berpikir kritis dapat dilatih pada siswa melalui pendidikan. Tujuannya untuk mempersiapkan siswa dalam menghadapi permasalahan yang dihadapkan pada pilihan dan situasi yang senantiasa mengalami perubahan. Menurut (Bassham, dkk, 2011:1) berpikir kritis merupakan suatu keterampilan kognitif untuk mengidentifikasi, menganalisis dan mengevaluasi argumen, mengatasi dugaan bersifat subjektif, merumuskan alasan yang logis, hingga membuat keputusan yang tepat.

Ilmu pengetahuan berkembang sangat pesat di abad 21 ini, salah satunya yaitu ilmu kimia. Ilmu kimia memiliki karakteristik menyajikan berbagai fenomena dalam kehidupan. Karakteristik ilmu kimia dapat dilihat dari aspek sub makroskopik, mikroskopik dan simbolik sehingga memerlukan keterampilan dan penalaran. Ketiga aspek tersebut saling berkaitan untuk mengembangkan kompetensi sehingga siswa mampu memahami dan menjelajahi fenomena yang terjadi alam. Berdasarkan alasan tersebut, seharusnya ilmu kimia menjadi pembelajaran yang mudah dipahami dan dianalisis karena berkaitan dengan fenomena yang ada dalam kehidupan sehari-hari sehingga membantu meningkatkan kemampuan berpikir kritis siswa. Namun kenyataannya berbeda, siswa takut dalam mempelajari kimia. Hal ini dapat disebabkan karena penggunaan model pembelajaran yang diterapkan guru berbasis teacher center atau model pembelajaran konvensional sehingga siswa bersifat pasif sehingga kurangnya kemampuan siswa dalam menganalisis suatu fenomena atau permasalahan yang diberikan dan berdampak terhadap kemampuan berpikir kritis siswa. Berdasarkan hasil observasi yang sudah dilakukan di sekolah, rata-rata nilai dari segi aspek kognitif siswa berada dibawah KKM yaitu 60,82 .

Berdasarkan hasil observasi yang dilakukan pada guru mata pelajaran kimia di MAN 2 Mataram, diperoleh informasi bahwa guru sering menerapkan model pembelajaran konvensional yang didominasi dengan metode ceramah, sehingga siswa hanya terpaku dengan pembelajaran yang ada di buku paket tanpa bisa mengaitkan konsep pembelajaran dengan kehidupan sehari-hari yang menyebabkan partisipasi siswa dalam pembelajaran kimia relatif rendah.

Berdasarkan uraian diatas, diperlukan strategi yang dapat meningkatkan kemampuan berpikir kritis siswa dan meningkatkan aktivitas siswa dalam belajar agar proses pembelajaran tidak monoton. Solusi yang ditawarkan dengan menghadirkan model pembelajaran yang inovatif yaitu Predict, Observe and Explain (POE) dengan tujuan agar proses pembelajaran lebih bermakna dan dapat mengatasi permasalahan dalam kehidupan sehari-hari. Adapun tahapan dalam model pembelajaran Predict, Observe and Explain (POE) yaitu: 1) Predict atau prediksi yaitu siswa membuat prediksi solusi permasalahan dan memperkirakan hasil dari yang akan dilakukan pada langkah berikutnya. Untuk membuat prediksi, siswa dibebaskan berpikir seluasluasnya sesuai dengan pengetahuannya tanpa batasan dari guru; 2) Observe atau observasi yaitu siswa mengamati atau melihat eksperimen. 3) Explain atau menjelaskan yaitu siswa membandingkan hasil pengamatan dalam observasi dengan prediksi kemudian membuat penjelasan berdasarkan pengetahuan sendiri (Muna, 2017; Anwar, 2019).

Materi yang cocok dengan penerapan model Predict, Observe and Explain (POE) ini yakni larutan elektrolit dan nonelektrolit. Materi larutan elektrolit dan nonelektrolit merupakan 


\section{Chemistry Education Practice,2 (2), 2019 - 16}

Lalu Ardian Gunawan, Sukib, Aliefman Hakim

salah satu materi kimia yang tidak lepas dari pemahaman secara utuh mengenai aspek sub mikroskopik, makroskopik dan simbolik. Materi larutan elektrolit dan nonelektrolit mampu meningkatkan kemampuan berpikir kritis siswa khususnya dalam menentukan larutan elektrolit kuat dan larutan elektrolit lemah. Hal tersebut dapat diketahui melalui sintak model Predict, Observe and Explain (POE) yang dapat mendorong kemampuan berpikir kritis karena siswa dituntut untuk memiliki kemampuan awal untuk memprediksikan jawaban permasalahan kemudian observasi langsung untuk membuktikan kebenaran prediksi, mengaitkan hasil observasi secara sub mikroskopik, makroskopik dan simbolik pada materi larutan elektrolit dan nonelektrolit sehingga mampu mendorong siswa berpikir kritis mengenai suatu fenomena.

Menurut Ennis (2011) indikator kemampuan berpikir kritis dibagi menjadi 5 besar aktivitas secara umum yaitu: (1) memberikan penjelasan sederhana (elementary clarification); (2) membangun keterampilan dasar (basic support); (3) membuat inferensi (inferring); membuat penjelasan lebih lanjut (advanced clarification); (5) mengatur strategi dan taktik (strategies and tactics). Namun, pada penelitian ini, peneliti hanya memilih dua indikator kemampuan berpikir kritis yakni kemampuan memberikan penjelasan sederhana dan menyimpulkan.

Berdasarkan penelitian sebelumnya dari Agustina (2013) menyatakan bahwa dengan menerapkan model Predict, Observe, Explain (POE) dapat meningkatkan kemampuan inferensi dan penguasaan konsep, penelitian Suyanto (2012) menyimpulkan bahwa dengan menerapkan model POE dapat meningkatkan kemampuan berpikir kreatif.

Berdasarkan uraian alasan diatas, peneliti tertarik untuk melakukan penelitian dengan judul "Pengaruh Model Pembelajaran Predict, Observe and Explain (POE) Terhadap Kemampuan Berpikir Kritis Siswa Materi Larutan Elektrolit dan Nonelektrolit Kelas X MIA MAN 2 Mataram".

\section{METODOLOGI PENELITIAN}

Penelitian ini dimulai dengan tahap persiapan penelitian dari bulan November 2018 dan kegiatan penelitian dilaksanakan pada bulan April-Mei 2019. Penelitian ini dilaksanakan di MAN 2 Mataram yang berlokasi di Jln.
Pendidikan No. 25, Gomong, Kota Mataram, pada kelas X MIA Semester II Tahun Ajaran 2018/2019.

Penelitian yang dilakukan berupa penelitian eksperimen, yaitu penelitian yang digunakan untuk mencari pengaruh perlakuan tertentu (Sugiyono, 2012). Jenis penelitian eksperimen yang digunakan adalah quasi experimental design. Desain penelitian yang digunakan dalam penelitian ini yaitu posttest only control group design. Pada desain ini kelompok eksperimen maupun kelompok kontrol dipilih menggunakan teknik purposive sampling. Penelitian dilakukan pada dua kelas, yaitu kelas eksperimen dan kelas kontrol. Perlakuan yang peneliti berikan pada kelas eksperimen berupa penerapan model pembelajaran Predict, Observe, Explain (POE) sedangkan pada kelas kontrol menggunakan model konvensional (ceramah). Pada masingmasing kelas hanya diberikan post-test. Desain penelitian yang dilakukan sesuai dengan Tabel 1.

Tabel 1. Rancangan Penelitian

\begin{tabular}{lclc}
\hline Kelas & $\begin{array}{c}\text { Pret } \\
\text { est }\end{array}$ & \multicolumn{1}{c}{ Perlakuan } & Post \\
& & & test \\
\hline $\begin{array}{l}\text { Eksperi } \\
\text { men }\end{array}$ & - & $\begin{array}{l}\text { Model Pembelajaran } \\
\text { Predict, Observe and } \\
\text { Explain (POE) }\end{array}$ & Ya \\
\hline Kontrol & - & $\begin{array}{l}\text { Model Pembelajaran } \\
\text { Konvensional }\end{array}$ & Ya \\
\hline
\end{tabular}

Variabel bebas dalam penelitian ini adalah model pembelajaran Predict, Observe and Explain (POE) yang diperlakukan untuk kelas eksperimen dan pembelajaran dengan model konvensional yanng diperlakukan untuk kelas kontrol. Variabel terikat pada penelitian ini adalah kemampuan berpikir kritis siswa.

Populasi pada penelitian ini yaitu seluruh siswa kelas X MIA MAN 2 Mataram berjumlah 153 orang dan tersebar dalam 4 kelas IPA, sampel yang digunakan dalam penelitian ini yaitu siswa kelas X MIA 2 yang jumlahnya 38 orang dan siswa Teknik pengambilan sampel yang digunakan yaitu teknik purposive sampling. Teknik purposive sampling merupakan teknik penentuan sampel dengan pertimbangan tertentu (Sugiyono, 2016: 67). 


\section{Chemistry Education Practice,2 (2), 2019 - 17}

Lalu Ardian Gunawan, Sukib, Aliefman Hakim

Penelitian ini menggunakan instrumen tes kemampuan kognitif siswa. Instrumen tes yang digunakan berupa essay yang terdiri dari 5 soal. Instrumen yang disusun terlebih dahulu diuji tingkat validitasnya dengan validitas isi intrumen menggunakan statistik Aiken's V dan validitas butir soal menggunakan Product Moment. Untuk menguji reliabilitas instrumen digunakan rumus Alpha Cronbach. Uji hipotesis dalam penelitian ini menggunakan Anova. Uji Anova dilakukan setelah data dianalisis dengan uji prasyarat yakni uji normalitas dan uji homogenitas.

\section{HASIL DAN PEMBAHASAN}

Penelitian ini bertujuan untuk mengetahui pengaruh model pembelajaran Predict, Observe and Explain (POE) terhadap kemampuan berpikir kritis siswa. Penggunaan model pembelajaran Predict, Observe and Explain (POE) diyakini dapat meningkatkan kemampuan berpikir kritis siswa dalam ranah kognitif. Masing-masing kelas diajar dengan materi yang sama yaitu larutan Elektrolit dan Nonelektrolit yang berlangsung selama 3 kali pertemuan.

Hasil diperoleh dari penelitian ini adalah hasil kemampuan berpikir kritis siswa yang diukur pada ranah kognitif dari hasil posttest. Peneliti memberikan posttest untuk mengetahui kemampuan berpikir kritis siswa setelah diberikan perlakuan. Setelah melakukan penelitian dengan menerapkan model pembelajaran Predict, Observe and Explain (POE) pada larutan Elektrolit dan Nonelektrolit, diperoleh hasil penelitian bahwa terdapat perbedaan nilai rata-rata hasil posttest antara siswa yang diajarkan menggunakan model pembelajaran Predict, Observe and Explain (POE) dengan siswa yang diajarkan menggunakan model pembelajaran konvensional. Berikut grafik rata-rata nilai posttest siswa:

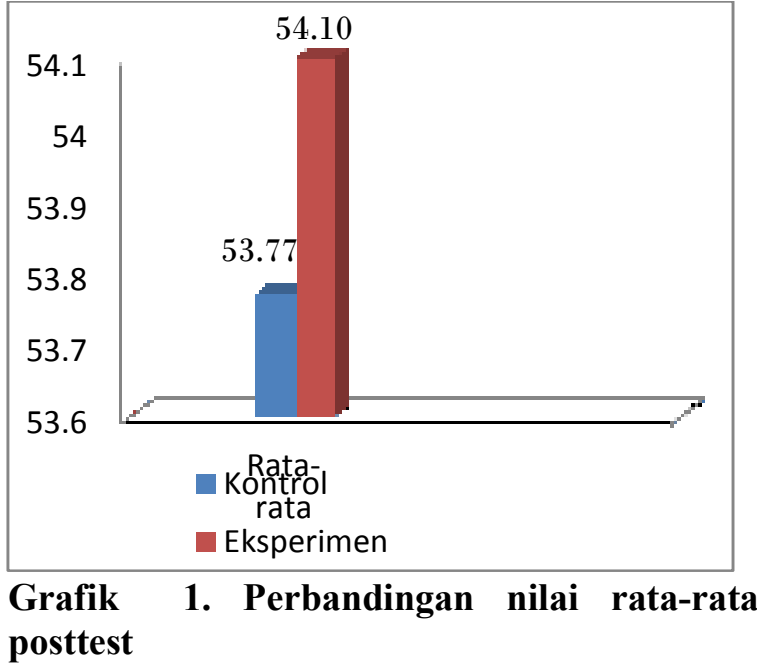

Grafik tersebut menunjukan perbedaan nilai rata-rata hasil post-test yang tidak cukup jauh pada kelas eksperimen dan kelas kontrol. Kedua nilai rata-rata yang didapatkan pada kelas kontrol dan kelas eksperimen tergolong rendah. Hal ini dibuktikan melalui hasil post-test yang diberikan berada dibawah standar (KKM). Hal ini disebabkan karena hanya sebagian siswa yang mampu mengingat secara keseluruhan serta mampu menjelaskan hasil percobaannya sehingga hasil post-test kedua kelas tidak jauh berbeda. Selain faktor tersebut, terdapat pengaruh yang berasal dari siswa itu sendiri, pada kelas kontrol frekuensi siswa yang mendapatkan nilai 80 keatas lebih banyak dibandingkan dengan yang mendapatkan nilai dibawah KKM yakni 75, meskipun diberikan model pembelajaran yang berbeda siswa tersebut tetap mendapat nilai yang tinggi karena memiliki tingkat kemampuan yang berbeda dengan siswa yang lain. Sehingga model Predict, Observe and Explain (POE) tidak memberikan pengaruh yang baik terhadap hasil post-test siswa.

Pada indikator kemampuan memberikan penjelasan sederhana sebagian besar siswa kurang mampu menjelaskan penyebab perbedaan hantaran listrik pada senyawa padatan, lelehan dan larutan serta menganalisis penyebab larutan elektrolit menghantarkan arus listrik. Untuk indikator memberikan kesimpulan sebagian besar siswa kurang mampu memberikan pendapat bahwa Larutan Elektrolit dan Nonelektrolit dapat berupa senyawa ion dan senyawa kovalen. Faktor lain yang mempengaruhi kemampuan berpikir kritis siswa yakni minat baca siswa yang rendah terhadap materi yang akan diajarkan. Sebelum dilakukannya sintak-sintak model pembelajaran 


\section{Chemistry Education Practice,2 (2), 2019 - 18}

Lalu Ardian Gunawan, Sukib, Aliefman Hakim

Predict, Observe and Explain (POE) terlebih dahulu siswa membangun keterampilan dasar dengan membaca literatur yang berkaitan dengan materi yang diajarkan. Menurut Zubaidah (2006) rendahnya minat baca siswa berdampak kepada kemampuan berpikir siswa, terutama kemampuan berpikir kritis siswa karena membaca merupakan sarana untuk mengembangkan kemampuan berpikir siswa. Melalui membaca dan memahami materi siswa semakin terdorong untuk bertambah kritis dan menimbulkan suasana yang proaktif.

Berdasarkan hasil lembar kerja siswa yang di berikan dan hasil post-test, siswa kurang mampu dalam menjelaskan penyebab terjadinya fenomena atau permasalahan tersebut. Selain itu, terdapat beberapa siswa yang belum mampu menjelaskan penyebab senyawa tidak dapat menghantarkan arus listrik. Kemudian dalam menyampaikan kesimpulan tidak semua siswa berani dalam menyampaikan simpulan. Hal ini dapat di ketahui melalui proses pembelajaran, siswa yang mampu mengemukakan pendapat hanya siswa yang memiliki antusias tinggi dalam belajar. Berdasarkan hasil observasi dan hasil post-test, dari tabel hasil pengamatan yang diberikan siswa belum mampu menyimpulkan hubungan jenis larutan dengan ikatan dari senyawa tersebut.

Pencapaian proses pembelajaran menggunakan model pembelajaran Predict, Observe and Explain (POE) dapat dilihat melalui persentase keaktifan siswa dalam setiap pertemuan pada proses pembelajaran yang dinilai oleh observer Berikut grafik nilai ratarata persentase aktivitas siswa pada kelas eksperimen dan kelas kontrol sebagai berikut:

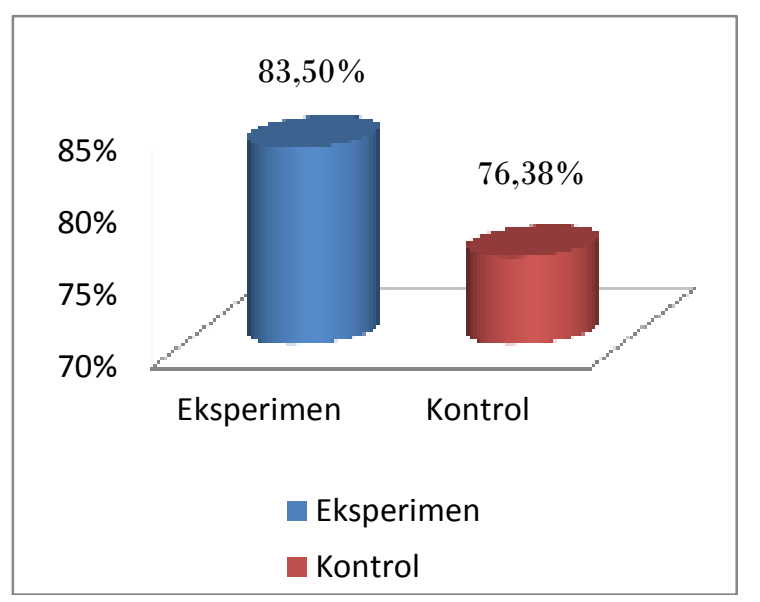

Grafik 3.2 Rata-rata aktivitas siswa

kelas eksperimen dan kelas control
Pada grafik tersebut dapat dilihat bahwa hasil observasi keaktifan siswa pada kelas eksperimen lebih tinggi dibandingkan dengan keaktifan siswa pada kelas kontrol. Tingginya aktivitas siswa pada kelas eksperimen dikarenakan kelas eksperimen menerapkan model pembelajaran Predict, Observe and Explain (POE) dimana guru sebagai motivator dan pemberi arah sementara siswa yang berperan aktif dalam proses pembelajaran. Keaktifan siswa juga dapat dilihat dari aktivitas bertanya siswa. Di kelas eksperimen siswa yang aktif bertanya dan mengemukakan pendapatnya lebih banyak dibandingkan kelas kontrol. Menurut Astuti (2011) tinggi rendahnya minat siswa terhadap mata pelajaran yang diajarkan berkaitan erat dengan rasa ingin tahu atau kebutuhan akan informasi yang salah satunya dengan mengajukan pertanyaan. Berdasarkan hasil analisis data tersebut, dapat diketahui bahwa model Predict, Observe and Explain (POE) berdampak positif dalam meningkatkan keaktifan siswa. Hal tersebut sesuai dengan pendapat dari Kurnia (2014) yang menyatakan model POE efektif untuk meningkatkan aktivitas belajar siswa. Selain faktor aktivitas siswa, dalam meningkatkan kemampuan berpikir kritis siswa terdapat beberapa faktor yang mempengaruhi baik faktor internal maupun eksternal siswa. Adapun beberapa faktor yang mempengaruhi kemampuan berpikir kritis menurut Sari, dkk (2016) yakni kondisi fisik, motivasi, kecemasan dan perkembangan intelektual.

Proses pembelajaran di kelas eksperimen diawali dengan pembagian kelompok yang beranggota 5-6 siswa. Kemudian dilanjutkan dengan kegiatan pendahuluan seperti pemberian apersepsi, motivasi dan dijabarkan tujuan pembelajaran yang ingin dicapai. Pemberian apersepsi tersebut sebagai bentuk stimulasi yang dapat memicu ketertarikan siswa terhadap pembelajaran yang akan dilaksanakan. Setelah kegiatan awal, dilanjutkan dengan kegiatan inti dimana pada proses pembelajaran dengan menggunakan model POE terdiri dari tiga tahapan yakni predict (prediksi), observe (observasi) dan explain (menjelaskan). Tahap awal dilakukan dengan proses memprediksi solusi dari permasalahan yang diberikan. Untuk memprediksi jawaban dari suatu permasalahan yang diberikan, diperlukan pengetahuan awal siswa sehingga siswa mampu memprediksi solusi yang tepat dari permasalahan tersebut. 


\section{Chemistry Education Practice,2 (2), 2019 - 19}

Lalu Ardian Gunawan, Sukib, Aliefman Hakim

Sebagian besar siswa sudah mampu melakukan tahap memprediksi solusi dari suatu masalah atau fenomena yang diberikan Tahap kedua dari model pembelajaran ini yaitu observe. Pada tahap observe siswa bertujuan untuk membuktikan kebenaran dari jawaban prediksi siswa. Hasil yang didapatkan dalam tahap observasi ini yaitu sebagian besar siswa sudah mampu melakukan observasi atau praktikum sederhana mengenai Larutan Elektrolit dan Nonelektrolit namun masih terdapat beberapa kelompok yang mendapatkan hasil tidak sesuai dengan teori karena pada proses pengamatan hasil observasi siswa kurang teliti dalam melihat ciri-ciri yang timbul dari larutan tersebut setelah diuji dengan alat uji Larutan Elektrolit dan Nonelektrolit. Tahap akhir dari proses pembelajaran yakni explain (menjelaskan) bertujuan untuk menjelaskan hasil praktikum apakah sesuai atau tidak dengan hasil prediksi awal siswa agar proses pembelajaran menjadi lebih bermakna dan memperluas pengetahuan siswa. Sesuai dengan pendapat Burhan, dkk (2014) yang menyatakan bahwa dalam diskusi kelompok siswa dapat menemukan sendiri konsep dengan mengerjakan latihan sehingga siswa mengetahui makna dari konsep-konsep yang dipelajari dan memperluas pengetahuan. Pada tahap explain, proses pembelajaran kurang maksimal, hanya perwakilan kelompok saja yang dapat menyampaikan hasil diskusinya sedangkan kelompok yang lain mendengarkan sehingga untuk mendapatkan jawaban yang bervariasi dari berbagai kelompok tidak berjalan dengan maksimal. Hasil yang didapatkan selama proses pembelajaran secara keseluruhan yakni siswa memiliki kekurangan dalam menganalisis persamaan reaksi proses ionisasi dari larutan elektrolit dan menjelaskan jenis ikatan atau bentuk zat yang termasuk larutan Elektrolit dan Nonelektrolit.

Berdasarkan hasil analisis data hipotesis penelitian pada taraf signifikan 5\% didapatkan hasil Ftabel sebesar 3,98 Fhitung $(0,00605)<$ Ftabel $(3,98)$ yang berarti $\mathrm{HO}$ diterima dan $\mathrm{Ha}$ ditolak. Untuk lebih memperkuat uji hipotesis, dapat dilihat dari nilai signifikansi terhadap kemampuan berpikir kritis siswa sebesar 5\% $(0,05)<$ sig. 0,938 yang berarti model pembelajaran Predict, Observe and Explain (POE) tidak memberikan pengaruh yang signifikan terhadap kemampuan berpikir kritis siswa pada materi larutan Elektrolit dan Nonelektrolit. Penelitian ini tidak sejalan dengan penelitian sebelumnya oleh Nurmalasari, dkk
(2016) yang menyatakan model Predict, Observe and Explain (POE) memberikan pengaruh signifikan terhadap kemampuan berpikir kritis. Keberhasilan penelitian ini dapat dipengaruhi oleh kegiatan evaluasi yang diberikan guru bukan hanya sekedar pemberian kesimpulan dan pemantapan materi pembelajaran pada tahap akhir pembelajaran, namun guru melakukan evaluasi lebih lanjut dengan pemberian tugas berupa soal yang berkaitan dengan materi yang diajarkan.

\section{KESIMPULAN}

Berdasarkan data hasil penelitian dan pembahasan, maka dapat disimpulkan bahwa model pembelajaran Predict, Observe and Explain (POE) tidak berpengaruh signifikan terhadap kemampuan berpikir kritis siswa pada materi Larutan Elektrolit dan Nonelektrolit kelas X MIA MAN 2 Mataram.

\section{SARAN}

Diharapkan penelitian selanjutnya tidak hanya mencakup ranah kognitif, melainkan mencakup ranah psikomotorik maupun tingkat berpikir kreatif dengan memperhatikan karakter siswa serta melakukan penelitian dengan menggunakan pendekatan model pembelajaran yang sama dapat diterapkan dalam materi yang berbeda.

\section{DAFTAR PUSTAKA}

Agustina, P; Noor, F; Chansyanah, D dan Nina, K. 2013. Peningkatan Keterampilan Inferensi dan Penguasaan Konsep Pada Materi Termokimia Melalui Model Pembelajaran POE. Pendidikan Kimia Universitas Lampung.

Astuti, Arni. 2009. Pembelajaran Kimia Dengan Pendekatan CTL (Contexual Teaching and Learning) Melalui Metode Proyek Dan Eksperimen Ditinjau Dari Sikap Ilmiah Dan Kemampuan Berkomunikasi Siswa (Studi Kasus Pada Materi Larutan Asam Basa Kelas XI IPA Semester 2 SMA Negeri I Surakarta Tahun Pelajaran 2008/2009). Surakarta.

Astuti, Y \& Setiawan, B. 2013.Pengembangan Lembar Kerja Siswa (LKS) Berbasis Pendekatan Inkuiri Terbimbing dalam 


\section{Chemistry Education Practice,2 (2), 2019 - 20}

Lalu Ardian Gunawan, Sukib, Aliefman Hakim

Pembelajaran Kooperatif pada Materi Kalor.Jurnal Pendidikan IPA Indonesia.3 (1).

Bassham, W; Nardone dan Irwin. 2011. Critical Thinking A Student's Introduction. New York: McGraw-Hill.

Burhan, A.V., Suherman., Mirna. 2014. Penerapan Model Pembelajaran Auditory Intellectually Repetition (AIR) Pada Pembelajaran Matematika Siswa Kelas VIII SMPN 18 Padang. Jurnal Education. 1(1). 1-8.

Ennis, R.H. 2011. The Nature of Critical Thinking: An Outline Of Critical Thinking Dispositions and Abilities. Chicago: University Of Illinois.

Kemdikbud. 2014. Modul Pelatihan Guru: Implementasi Kurikulum 2013 Mata Pelajaran Sosiologi SMA/SMK Tahun 2014/2015. Jakarta: Kemdikbud.

Muna, I.A. 2017. Model Pembelajaran POE (Preidict, Observe and Explain) Dalam Meningkatkan Pemahaman Konsep dan Keterampilan Proses IPA. Jurnal Studi Agama. 5(1). 17-26.

Nurmalasari, A.L; Jayadinata, A.K dan Maulana. 2016. Pengaruh Strategi Predict, Observe and Explain (POE) Berbantuan Permainan Tradisional Siswa pada Materi Gaya. Jurnal Pena Ilmiah. Vol 1(1): 181190.

Sari, W. P; Suyanto, E dan Suana, W. 2016. Analisis Pemahaman Konsep Vektor pada Siswa Sekolah Menengah Atas. Jurnal Ilmiah Pendidikan Fisika Al-Biruni. 6(2): 52-62.

Suyanto, Y.P; Susanto, H dan Linuwih, S. 2012. Efektifitas Penggunaan Strategi Predict, Observe and Explain (POE) untuk Meningkatkan Kemampuan Berpikir Kritis dan Kreatif Siswa. Semarang: Universitas Negeri Semarang.

Sugiyono. 2012. Metode Penelitian Kuantitatif, Kuantitatif dan $\mathrm{R} \& \mathrm{D}$. Bandung: Alfabeta.
2016. Statistika Untuk Penelitian. Bandung: ALFABETA.

Anwar, Y. A. S. (2019). Pengaruh Model Pembelajaran Predict-Observe-Explain (POE) Terhadap Pemahaman Konsep Siswa Materi Kesetimbangan Kelarutan Kelas XI MIA SMAN 2 Labuapi Tahun Ajaran 2017/2018. Chemistry Education Practice, 1(2), 27-35.

Zubaidah, S; Ardian, A.P dan Herawati, S. 2006. Penerapan Model Pembelajaran Biologi Berbasis Reading-Concept Map-Teams Games Tournaments untuk Meningkatkan Kemampuan Berpikir Kritis dan Hasil Belajar Kognitif Siswa Kelas X IPA 4 SMA Laboratorium UM. Seminar Nasional XI Pendidikan Biologi FKIP UNS: 963-968. 